\section{Urban road traffic deaths: data linkage and identification of high-risk population sub-groups}

\author{
Óbitos no trânsito urbano: qualificação da \\ informação e caracterização de grupos \\ vulneráveis
}

\author{
Óbitos en el tráfico urbano: calificación de \\ la información y caracterización de \\ grupos vulnerables
}

Lúcia Maria Miana Mattos Paixão 1,2

Eliana Dias Gontijo 1

Sueli Aparecida Mingoti 2,3

Dário Alves da Silva Costa 1,2 Amélia Augusta de Lima Friche 1,2 Waleska Teixeira Caiaffa 1,2

\author{
${ }^{1}$ Faculdade de Medicina, \\ Universidade Federal de \\ Minas Gerais, Belo Horizonte, \\ Brasil. \\ 2 Observatório de Saúde \\ Urbana de Belo Horizonte, \\ Belo Horizonte, Brasil. \\ 3 Instituto de Ciências Exatas, \\ Universidade Federal de \\ Minas Gerais, Belo Horizonte, \\ Brasil. \\ Correspondence \\ L. M. M. M. Paixão \\ Rua Maranhão 1567, apto. \\ 302, Belo Horizonte, $M G$ \\ 30150-331, Brasil. \\ lucia.paixao@pbh.gov.br
}

\begin{abstract}
This study analyzes the profile of deaths from road traffic accidents in Belo Horizonte, Minas Gerais State, Brazil, by linking two public databases, the Information System of the Urban Transportation and Transit Company (BH1O) and the Mortality Information System (SIM). The linked database $(n=306)$ identified a $24 \%$ under-recording rate for deaths and differed in the age distribution from the BHIO database and in roadway user category when compared to the mortality database. The mortality rate for road traffic accidents within the city limits was 10.2 per 100,000 thousand, and was higher among men, young adults, and the elderly. Poisson multivariate regression showed a higher mean death rate for motorcycle occupants (rate ratio - RR: 1.81); pedestrians (RR: 1.32); males (RR: 1.24); singleldivorced (RR: 1.27); young adults 18-29 years of age (RR: 1.75); elderly (RR: 1.59); and deaths at the crash site (RR: 1.39) when compared to the reference categories. The study unveils the city's traffic violence, expressed by the large proportion of deaths at the crash site and within the first 24 hours, and confirms the relevance of database linkage for characterizing vulnerable groups and traffic accident mortality in the urban setting.
\end{abstract}

Traffic Accidents; Mortality; Information System; Urban Health

\section{Resumo}

O estudo compara o perfil de óbitos por acidentes de trânsito em Belo Horizonte, Minas Gerais, Brasil, entre dois sistemas públicos de informação $e$ os caracteriza valendo-se do cruzamento das bases de dados do trânsito (BH1O) e de mortalidade $(S I M)$. O banco relacionado $(n=306)$ apontou sub-registro de $24 \%$ dos óbitos e diferiu na distribuição etária com o BH10 e dos usuários da via com o SIM. A taxa de mortalidade no perímetro urbano de 10,2 por 100 mil residentes foi maior entre homens, jovens e idosos. A regressão multivariada de Poisson apontou maior número médio esperado de óbitos entre ocupantes de motocicleta (razão de médias - RM: 1,81); pedestres (RM: 1,32); homens (RM: 1,24); solteiros/separados (RM: 1,27); jovens de 18-29 anos (RM: 1,75); idosos (RM: 1,59); e no local do acidente (RM: 1,39), comparados às categorias de referência. O estudo descortina a violência no trânsito traduzida pela maior ocorrência dos óbitos na via e nas primeiras 24 horas, e confirma a relevância do relacionamento de sistemas de informação para caracterizar os grupos vulneráveis e os óbitos por acidentes de trânsito em ambiente urbano.

Acidentes de Trânsito; Mortalidade; Sistemas de Informação; Saúde Urbana 


\section{Introduction}

Road traffic accidents are a serious global public health problem, associated with behavioral factors, vehicle safety, and the precarious urban environment. They are major causes of injury and death due to the growing number of vehicles, lifestyle changes, and risk behaviors in the general population 1.

Worldwide, an estimated 50 million persons per year suffer injuries and disabilities from road traffic accidents, with 1.3 million deaths, $62 \%$ of which are concentrated in ten countries. Brazil ranks fifth, after China, India, Russia, and the United States 2.

Epidemiological studies have shown that road traffic accidents display different patterns according to gender, age, social group, and risk area, revealing increased vulnerability for individuals and places 3,4 . Accidents should thus be approached from an urban health perspective, integrating characteristics of urban residents' health with those of the built environment 5 .

Growing motor vehicle traffic, especially in developing countries and in the absence of adequate roadway infrastructure and efficient penalization of traffic violations, has fueled the increase in road traffic accidents, thus shaping so-called "urban chaos", requiring complex solutions and interventions to build a safe traffic environment 6,7 .

In Brazil, the number of deaths and serious injuries from traffic accidents now exceeds 150,000 victims per year, at an annual cost of some 28 billion reais (11 million dollars), in addition to the high social costs from medical care, material losses, social security expenditures, the immeasurable suffering of victims and families 7,8 . Since Haddon Jr. ${ }^{9}$ proposed the holistic model by which traffic injuries result from the interaction between persons (host factors), energy (vehicle factors), and the environment, the former dichotomy between health planning and urban planning is now outdated. Epidemiological analyses of accidents and victims should be used in interdisciplinary and inter-sector urban planning as an effective accident prevention strategy, fostering a protective environment, especially for more vulnerable groups 5 .

Enactment of the Brazilian Traffic Code in 1998 and the complementary legislation, municipal traffic control, improved vehicle safety, and electronic inspection and surveillance are important initiatives, but insufficient to significantly reduce deaths and disabilities 8 . Among other factors, the severity of this scenario led the Brazilian Ministry of Health to implement the National Policy to Reduce Morbidity and Mortal- ity from Accidents and Violence in 200110 and to create the Project for Surveillance of Violence and Accidents (VIVA) in 2006, the objectives of which include the description of emergency care involving cases of violence and accidents and the distribution, magnitude, and trends of such injuries 11 .

In 2009, the United Nations declared the period from 2011 to 2020 as the Decade of Action for Road Safety, urging countries (including Brazil) to stabilize and reduce traffic deaths by implementing an action plan focused on five pillars: road safety management; safer roads and mobility; safer vehicles; safer road users; and post-crash response. Thus, in 2010 Brazil launched the Life in Traffic Project - the name for the Road Safety Project in 10 countries - RS10 (WHO/PAHO). The initiative, coordinated by the Ministry of Health, aims to strengthen policies to prevent road traffic injuries and deaths by improving information, planning, monitoring, and evaluation of interventions 12 .

Prevention of road traffic accidents requires knowledge of the occurrences, the victims' profile, means of transportation involved, and identification of high-risk areas 13 , and is hindered by the dispersal of data in diverse information systems. Database linkage thus helps unveil the true magnitude of such accidents 14,15.

The Life in Traffic Project in Belo Horizonte, Minas Gerais State, Brazil, has observed discrepancies in independent analyses of the different information systems, due to the deficiencies attributed to police records, which almost exclusively record deaths at the crash sites, and the fact that records from the Mortality Information System (SIM) often fail to allow identification of a road traffic accident as the underlying cause of death.

The urban health approach to road traffic accidents by linking and upgrading available databases allows comparing diverse sources 14,15 , thereby contributing to the implementation, development, and monitoring of integrated policies for the prevention of such accidents.

Assuming the hypothesis that upgrading such information can unveil the true vulnerability profile of fatal victims, the current study aims to link two information systems generated by different organizational sectors in the city, namely the Urban Transportation and Transit Company and the Municipal Health Secretariat, constructing a linked database for deaths from traffic accidents in the city of Belo Horizonte, , with a view towards describing the victims' profile and identifying vulnerabilities among users of the city's roads. 


\section{Methods}

This study linked two information systems: the Information System of the Empresa de Transportes and Trânsito de Belo Horizonte S/A BHTRANS (BH10) (Belo Horizonte Urban Transportation and Transit Company) and the SIM, described below, resulting in a database called BH10-SIM. This linked database included victims of traffic accidents that occurred within the city limits in the year 2010 that evolved to death and were identified in the SIM in the years 2010 and 2011. The analysis also included fatal victims of crashes that occurred on highways inside the city limits.

\section{Linkage procedures for the $\mathrm{BH} 10$ and} SIM databases

BH10 includes road traffic accidents with victims, recorded by the local law enforcement agency on police crash reports and with the following information: type of accident, circumstances, location, persons involved, and the injured or dead.

SIM is an information system based on death certificates, and is part of the country's epidemiological surveillance system. Municipal Health Secretariats are responsible for recording deaths in the city, complemented by system feedback with data on deaths of city residents that occur elsewhere. Death certificates for road traffic accidents (one of the external causes) are issued by the Forensic Medical Examiner's Office (IML, in Portuguese) and recorded in the SIM 16.

In 2010, the BH10 base recorded 37,550 individuals involved in road traffic accidents (with or without injuries), and the SIM base recorded a total of 41,080 deaths in Belo Horizonte from January 1st, 2010, to December 31 st, 2011.

Data from the two systems were then linked using Link Plus (Centers for Disease Control and Prevention; http://www.cdc.gov/cancer/npcr/ tools/registryplus/lp.htm), with the victims' full name and age as the key variables. The software allows probabilistic data linkage, using phonetic coding systems. In addition to the exact correspondence method, it identifies partial, approximate, or dubious similarities, thus preventing spelling differences or typos from interfering in the identification of true pairs.

The initial linkage identified 1,072 pairs. This was followed by manual verification for the final selection of true pairs, by identification of victims of traffic accidents that died on site or evolved to death after the crash and within the target period. The following information was used to compare the pairs: name, date of birth or age, interval between the time of the crash and death, and underlying cause of death. The linked database resulted in 311 records of fatal victims of traffic accidents in the city of Belo Horizonte in 2010. Five records were excluded due to incomplete information, totaling 306 records for analysis (Figure 1).

\section{Comparison of original databases with the linked database (BH10-SIM)}

To compare the SIM 2010 database with the linked base ( $\mathrm{n}=306)$, we selected the death records for road traffic accidents from the former, using codes V01-V89 of the International Statistical Classification of Diseases and Related Health Problems (ICD-10). Coding was grouped into seven categories called "roadway users": pedestrians, bicycle occupants, motorcycle occupants, automobile occupants, heavy vehicle occupants, others, and unspecified.

To compare the linked bank to $\mathrm{BH} 10$, which included all individuals involved in crashes with victims, we selected the victims that were recorded as fatal.

The databases were compared by gender, age bracket, and type of roadway user.

\section{Variables in the linked database}

The variables comprising the linked database were: roadway user (pedestrians, bicycle occupants, motorcycle occupants, automobile occupants, heavy vehicle occupants); age (in years); age bracket $(\leq 17,18-29,30-39,40-49,50-59$, and $\geq 60$ years); gender (male, female); skin color (white, brown/black); schooling ( $\leq 3,4-7,8-11$, and $\geq 12$ years); marital status (married, single/ divorced, widowed), and place of death (public roadway, hospital).

The variable "interval", or time transpired between the crash and death, was created and grouped into three categories: $<24$ hours; 1 to 29 days; and $\geq 30$ days.

The variable referred to operationally as "place and time of death" as part of the information on the place where death occurred and the time interval between the crash and death, was categorized as: death at the crash site (on the public roadway) or in-hospital within the first 24 hours, from 1 to 29 days, and 30 days or more.

\section{Data analysis}

The data were analyzed in stages. The first stage compared the databases and the second used multivariate analysis of the linked database. The first stage used comparison of the proportions for roadway user, age bracket, and gender be- 


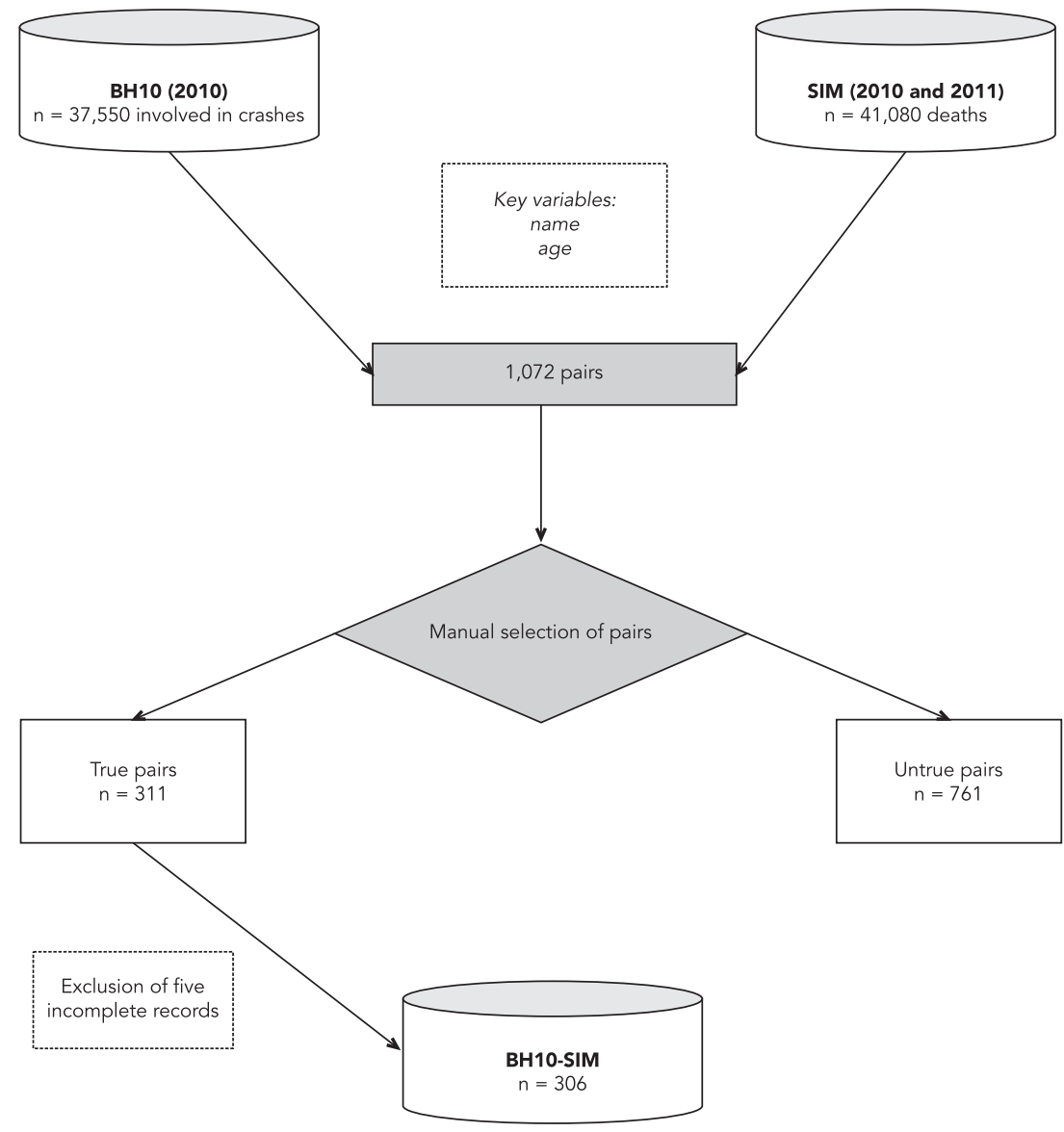

BH10: Information System of the Belo Horizonte Urban Transportation and Transit Company; BH10-SIM: linkage of BH10 and SIM databases; SIM: Mortality Information System.

tween the original databases and the linked base, by means of the $\chi^{2}$ (chi-square) test.

The denominator for calculating age and gender-specific mortality rates for residents of Belo Horizonte used the population data from the 2010 Census (Instituto Brasileiro de Geografia e Estatística; http://www.censo2010. ibge.gov.br/painel/?nivel=mn, accessed on 15/ Jan/2013).

Finally, Poisson regression 17,18 was used to model the behavior of the mean number of deaths in the study period as a function of reference variables for the victims' profile and circumstances of the accidents, including the place and the time between the crash and death.
Based on univariate analysis, variables with statistical significance greater than or equal to $20 \%$ were included in the multivariate model. Skin color $(\mathrm{p}=0.23$ ) was included due to its epidemiological relevance.

The final multivariate model was constructed by stepwise introduction of the previously selected variables, starting with "roadway user", to identify the most adequate and parsimonious model. The Omnibus test 19 was used to verify the models' adequacy and the Wald statistical test to assess the variables' significance. Mean number of deaths was estimated as a function of the explanatory variables. The regression model coefficients $\left(\mathrm{e}^{\mathrm{B}}=\right.$ exponential of the regression 
coefficient) express the ratio between the mean number of deaths (RR - known in the literature as "rate ratio") in each category and the reference category, maintaining the other variables constant. Statistical significance was set at $5 \%$, with a 95\% confidence interval.

Data analysis used R 2.8.1 (The R Foundation for Statistical Computing, Vienna, Austria; http:/ / www.r-project.org) and SPSS 17.0 (SPSS Inc., Chicago, USA).

The study was approved by the Ethics Research Committee of Universidade Federal de Minas Gerais and the Belo Horizonte Municipal Health Secretariat (case reviews 158.014/2012 and 182.177/2012).

\section{Results}

\section{Original databases and linked database}

The BH10 database included 247 deaths from police crash reports for deaths that occurred inside the Belo Horizonte city limits in the year 2010 . The SIM database yielded 625 deaths from road traffic accidents. These corresponded to accidents that occurred in the same year both in Belo Horizonte and elsewhere, the deaths of which occurred in Belo Horizonte, according to the SIM protocol.

Database linkage (called BH10-SIM) resulted in 306 records, representing the deaths from road traffic accidents that occurred in the city of Belo Horizonte in 2010.

The study showed $24 \%$ under-recording, or 59 deaths identified in the linked database and not recorded in the police reports (BH10).

\section{Comparison of the original databases and the linked database (BH10-SIM)}

Comparison of the linked database (BH10-SIM) and $\mathrm{BH} 10$ showed a significant difference in the age distribution $(p=0.001)$, and database linkage showed a higher percentage of deaths in individuals $\geq 60$ years of age. Meanwhile, comparison of the linked database and the SIM showed a different distribution in the roadway user category ( $p=0.015)$, with a higher proportion of fatal victims among motorcycle occupants and pedestrians, and a lower proportion of automobile occupants in the BH10-SIM database (Table 1).

As for gender, BH10-SIM showed a similar distribution of deaths in males and females, in the comparison with both BH10 and SIM $(\mathrm{p}>0.05)$.
Mortality rates by specific cause, age, and gender

Of the 306 deaths in Belo Horizonte, 238 (78\%), were residents of the city, resulting in a road traffic accident mortality rate in the city limits of $10.02 / 100.000$ inhabitants; the rate was higher in men (17.06) than in women (3.80). Increased risk of dying from road traffic accidents, per 100,000 inhabitants, was identified among the elderly (18.36) and young people 18 to 29 years of age (15.03).

\section{Analysis of the characteristics of fatal victims}

Some $82 \%$ of fatal victims were males, more than half were young adults, $60 \%$ were brown/black, and $68 \%$ were single or divorced. Nearly half $(47 \%)$ of the fatal victims had fewer than eight years of schooling. The elderly accounted for $21 \%$ of the victims (Table 2).

Pedestrians (49\%) and motorcycle occupants (31\%) totaled $80 \%$ of the deaths, signaling the vulnerability of these groups. Automobile occupants accounted for $15 \%$ and heavy vehicle and bicycle occupants fewer than $3 \%$ each (Table 2).

Joint analysis of the crash site and time between the crash and death showed 125 deaths (41\%) on the public roadways and 79 deaths (26\%) in the hospital within 24 hours after admission, totaling 204 of deaths $(67 \%)$ in the first 24 hours. Of the 181 victims that were rushed to hospitals and later died, the severity of injuries is shown by the high proportion of deaths within 24 hours (44\%). Only $7 \%$ of deaths occurred 30 days after the accident or later.

In the three main categories of "roadway users", $82 \%$ of the 45 automobile occupants died in the first 24 hours, including $60 \%$ at the crash site (on public roadways). $74 \%$ of the 95 deaths of motorcycle occupants occurred in the first 24 hours after the accident, nearly half $(48 \%)$ on the public roadway. Although $60 \%$ of pedestrians died in the first 24 hours, in this same group nearly one-third of deaths occurred between one and 29 days (31\%). More than half $(53 \%)$ of the occupants of bicycles and heavy vehicles died in hospital (Figure 2).

As for the 125 deaths on public roadways, pedestrians and motorcycle occupants showed similar proportions, 36 and $37 \%$, respectively. However, in hospital, regardless of the time since the accident, pedestrians were invariably the predominant group (Figure 2).

Age distribution differed as to the "roadway user" variable, crash site, and time between the crash and death. Among pedestrians, $40 \%$ were 60 years or older. Meanwhile, young adults 18 to 
Distribution of traffic accident deaths by age bracket, gender, and roadway user category according to the SIM, BH10, and BH10-SIM databases. Belo Horizonte, Minas Gerais State, Brazil, 2010.

\begin{tabular}{|c|c|c|c|c|c|c|c|c|}
\hline & \multicolumn{3}{|c|}{$\operatorname{SIM}(n=625)$} & \multicolumn{3}{|c|}{ BH10-SIM $(n=306)$} & \multicolumn{2}{|c|}{$\mathrm{BH} 10(n=247)$} \\
\hline & $\mathbf{n}$ & $\%$ & $\mathrm{p}$-value * & $\mathbf{n}$ & $\%$ & $\mathrm{p}$-value * & $\mathbf{n}$ & $\%$ \\
\hline \multicolumn{9}{|l|}{ Age bracket (years) } \\
\hline$\leq 17$ & 40 & 6.40 & & 12 & 3.92 & & 9 & 3.64 \\
\hline $18-29$ & 170 & 27.20 & & 99 & 32.35 & & 82 & 33.20 \\
\hline $30-39$ & 115 & 18.40 & & 57 & 18.63 & & 48 & 19.43 \\
\hline $40-49$ & 84 & 13.44 & & 39 & 12.75 & & 29 & 11.74 \\
\hline $50-59$ & 87 & 13.92 & & 35 & 11.44 & & 25 & 10.12 \\
\hline$\geq 60$ & 129 & 20.64 & & 64 & 20.92 & & 38 & 15.38 \\
\hline Data missing & 0 & 0.00 & & 0 & 0.00 & & 16 & 6.48 \\
\hline BH10-SIM vs. SIM & & & 0.392 & & & & & \\
\hline $\mathrm{BH} 10-\mathrm{SIM}$ vs. $\mathrm{BH} 10$ & & & & & & 0.001 & & \\
\hline \multicolumn{9}{|l|}{ Gender } \\
\hline Male & 499 & 79.84 & & 250 & 81.70 & & 203 & 82.19 \\
\hline Female & 126 & 20.16 & & 56 & 18.30 & & 43 & 17.41 \\
\hline Data missing & 0 & 0.00 & & 0 & 0.00 & & 1 & 0.40 \\
\hline BH10-SIM vs. SIM & & & 0.559 & & & & & \\
\hline $\mathrm{BH} 10-\mathrm{SIM}$ vs. $\mathrm{BH} 10$ & & & & & & 0.521 & & \\
\hline \multicolumn{9}{|l|}{ Roadway users } \\
\hline Pedestrians & 249 & 39.84 & & 148 & 48.37 & & 108 & 43.72 \\
\hline Automobile occupants & 143 & 22.88 & & 45 & 14.71 & & 50 & 20.24 \\
\hline Bicycle occupants & 19 & 3.04 & & 9 & 2.94 & & 3 & 1.21 \\
\hline Motorcycle occupants & 156 & 24.96 & & 96 & 31.37 & & 76 & 30.77 \\
\hline Heavy vehicle occupants & 18 & 2.88 & & 8 & 2.61 & & 6 & 2.43 \\
\hline Occupants of other vehicles ** & 8 & 1.28 & & 0 & 0.00 & & 1 & 0.40 \\
\hline Unspecified $\star \star$ & 32 & 5.12 & & 0 & 0.00 & & 3 & 1.21 \\
\hline BH10-SIM vs. SIM & & & 0.015 & & & & & \\
\hline $\mathrm{BH} 10-\mathrm{SIM}$ vs. $\mathrm{BH} 10$ & & & & & & 0.291 & & \\
\hline
\end{tabular}

BH10: Information System of the Belo Horizonte Urban Transportation and Transit Company; BH10-SIM: linkage of BH10 and SIM databases; SIM: Mortality Information System.

* $\chi^{2}$ test;

$\star \star$ Excluded from the analysis.

29 years of age predominated among motorcycle occupants (59\%) automobile occupants (49\%) and other groups (41\%) (Figure 2).

Nearly half of the deaths $(48.5 \%)$ in the 18 to 29-year age bracket occurred on the public roadways, totaling 72 deaths $(73 \%)$ in the first 24 hours. Meanwhile, children and adolescents (< 18 years) and elderly ( $\geq 60$ years) showed lower proportions of deaths at the crash site (less than $20 \%$ ). However, only $8 \%$ of individuals under 18 years died within 24 hours of hospital admission, while this proportion reached $38 \%$ in the elderly (Figure 2).

The profile of victims differed in the stratification of deaths according to the "roadway user" variable. Among deaths of pedestrians, $72 \%$ were males, with a mean and median age of 54 years
(SD $=22.3), 61 \%$ brown $/$ black, $46 \%$ married or widowed, and $68 \%$ with low schooling ( $<8$ years) (data not shown).

Nearly all motorcycle occupants were males (97\%), with a mean age of 28.9 years $(S D=9.3$ ) and median of 26 years, brown/black ( $54 \%$ ), single or divorced (78\%), with 8 to 11 years of schooling $(60 \%)$. Men were also the main fatal victims among automobile occupants (76\%), with a mean age of 33.2 years $(S D=12.9)$ and median of 29 years, brown/black skin color (58\%), and single or divorced (80\%), and were the group with the highest percentage of more than 11 years of schooling (29\%) (data not shown).

Of the 56 women that died, $75 \%$ were pedestrians and only three were motorcycle occupants. More than $60 \%$ died in the first 24 hours, with 
Table 2

Distribution of deaths and results of univariate Poisson regression according to demographics, roadway user category, crash site, and time between crash and death. Belo Horizonte, Minas Gerais State, Brazil, 2010.

\begin{tabular}{|c|c|c|c|c|c|c|}
\hline Variable & n (306) & $\%$ & B & $p$-value & RR & $95 \% \mathrm{Cl}$ \\
\hline \multicolumn{7}{|l|}{ Roadway users } \\
\hline Pedestrians & 149 & 48.69 & 0.102 & 0.419 & 1.110 & $0.865-1.416$ \\
\hline Motorcycle occupants & 95 & 31.05 & 0.519 & 0.004 & 1.680 & $1.180-2.391$ \\
\hline Automobile occupants & 45 & 14.71 & 0.09 & 0.501 & 1.090 & $0.843-1.420$ \\
\hline Bicycle occupants & 9 & 2.94 & -0.134 & 0.249 & 0.880 & $0.697-1.098$ \\
\hline Heavy vehicles & 8 & 2.61 & - & & 1.000 & - \\
\hline \multicolumn{7}{|l|}{ Gender } \\
\hline Male & 250 & 81.7 & 0.252 & 0.003 & 1.287 & $1.091-1.517$ \\
\hline Female & 56 & 18.3 & - & & 1.000 & - \\
\hline \multicolumn{7}{|l|}{ Age bracket (years) } \\
\hline$\geq 60$ & 64 & 20.92 & 0.267 & $<0.001$ & 1.306 & $1.137-1.500$ \\
\hline $50-59$ & 35 & 11.44 & 0.26 & 0.008 & 1.296 & $1.071-1.569$ \\
\hline $40-49$ & 39 & 12.75 & 0.198 & 0.065 & 1.219 & $0.988-1.504$ \\
\hline $30-39$ & 57 & 18.63 & 0.236 & 0.003 & 1.267 & $1.083-1.482$ \\
\hline $18-29$ & 99 & 32.35 & 0.606 & $<0.001$ & 1.833 & $1.415-2.376$ \\
\hline$\leq 17$ & 12 & 3.92 & - & & 1.000 & - \\
\hline \multicolumn{7}{|l|}{ Race/Color } \\
\hline Black/Brown & 178 & 58.17 & 0.118 & 0.235 & 1.126 & $0.925-1.370$ \\
\hline White & 128 & 41.83 & & & 1.000 & \\
\hline \multicolumn{7}{|l|}{ Schooling (years) } \\
\hline$\leq 3$ & 54 & 17.65 & 0.038 & 0.695 & 1.038 & $0.860-1.253$ \\
\hline $4-7$ & 89 & 29.08 & 0.163 & 0.117 & 1.177 & $0.960-1.441$ \\
\hline $8-11$ & 124 & 40.52 & 0.297 & 0.02 & 1.345 & $1.047-1.727$ \\
\hline$\geq 12$ & 39 & 12.75 & - & & 1.000 & - \\
\hline \multicolumn{7}{|l|}{ Marital status } \\
\hline Widowed & 17 & 5.56 & 0.079 & 0.63 & 1.082 & $0.785-1.489$ \\
\hline Single/Divorced/Separated & 208 & 67.97 & 0.213 & 0.02 & 1.238 & $1.034-1.481$ \\
\hline Married & 81 & 26.47 & 0.000 & & 1.000 & - \\
\hline \multicolumn{7}{|l|}{ Place of death } \\
\hline Roadway & 125 & 40.85 & 0.202 & 0.084 & 1.224 & $0.973-1.538$ \\
\hline Hospital & 181 & 59.15 & - & & 1.000 & - \\
\hline \multicolumn{7}{|l|}{ Interval * } \\
\hline$<24$ hours & 204 & 66.67 & 0.291 & 0.003 & 1.337 & $1.107-1.615$ \\
\hline $1-29$ days & 81 & 26.47 & 0.167 & 0.085 & 1.182 & $0.977-1.429$ \\
\hline$\geq 30$ days & 21 & 6.86 & - & & 1.000 & - \\
\hline \multicolumn{7}{|l|}{ Place and time of death ** } \\
\hline Roadway & 125 & 40.85 & 0.359 & 0.004 & 1.432 & $1.122-1.825$ \\
\hline Hospital (< 24 hours) & 79 & 25.82 & 0.192 & 0.055 & 1.211 & $0.995-1.474$ \\
\hline Hospital (1-29 days) & 81 & 26.47 & 0.167 & 0.085 & 1.182 & $0.977-1.429$ \\
\hline Hospital ( $\geq 30$ days) & 21 & 6.86 & - & & 1.000 & - \\
\hline
\end{tabular}

95\% Cl: 95\% confidence interval; RR: rate ratio.

* Time elapsed between crash and death;

** Variable created from the variables place of death and time between crash and death. 
Figure 2

Percentage distribution of deaths according to roadway user category and place of death and time between crash and death (2a), roadway user and age bracket (2b), age bracket and place and time (2c), place and time and roadway user (2d). Belo Horizonte, Minas Gerais State, Brazil, 2010.

2a) Place of death and time between crash and death

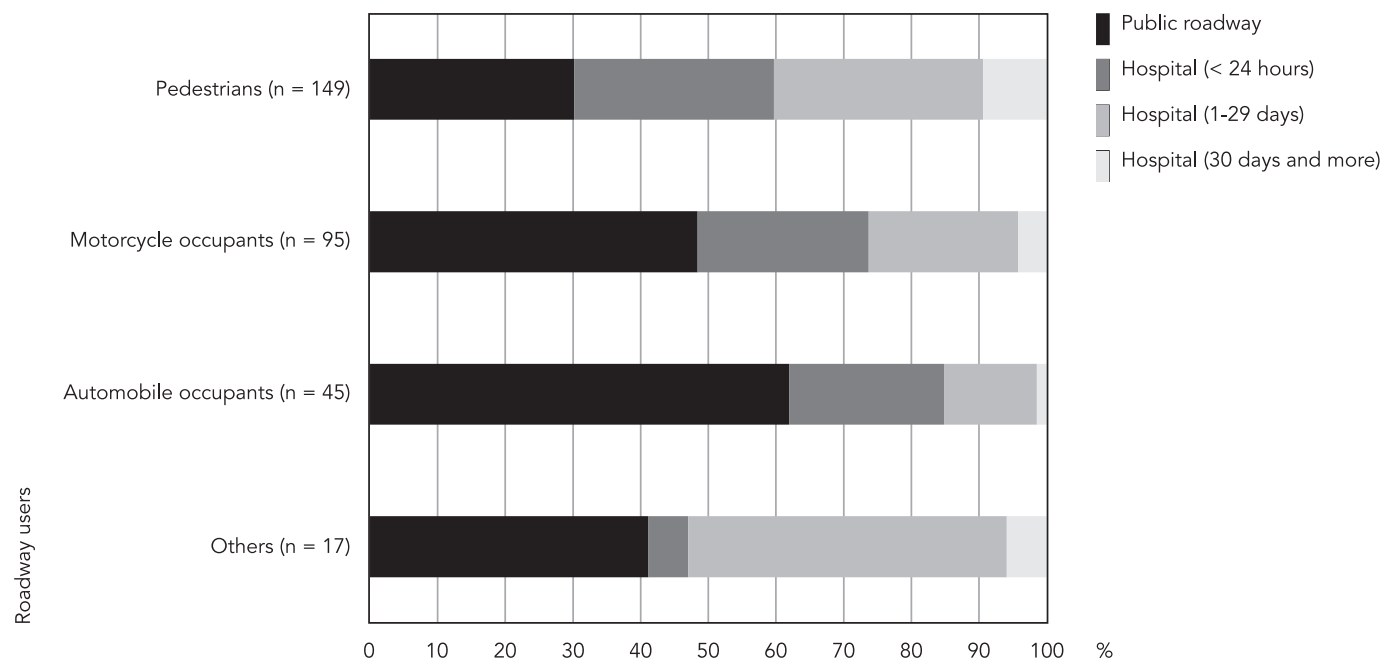

2b) Roadway user and age bracket

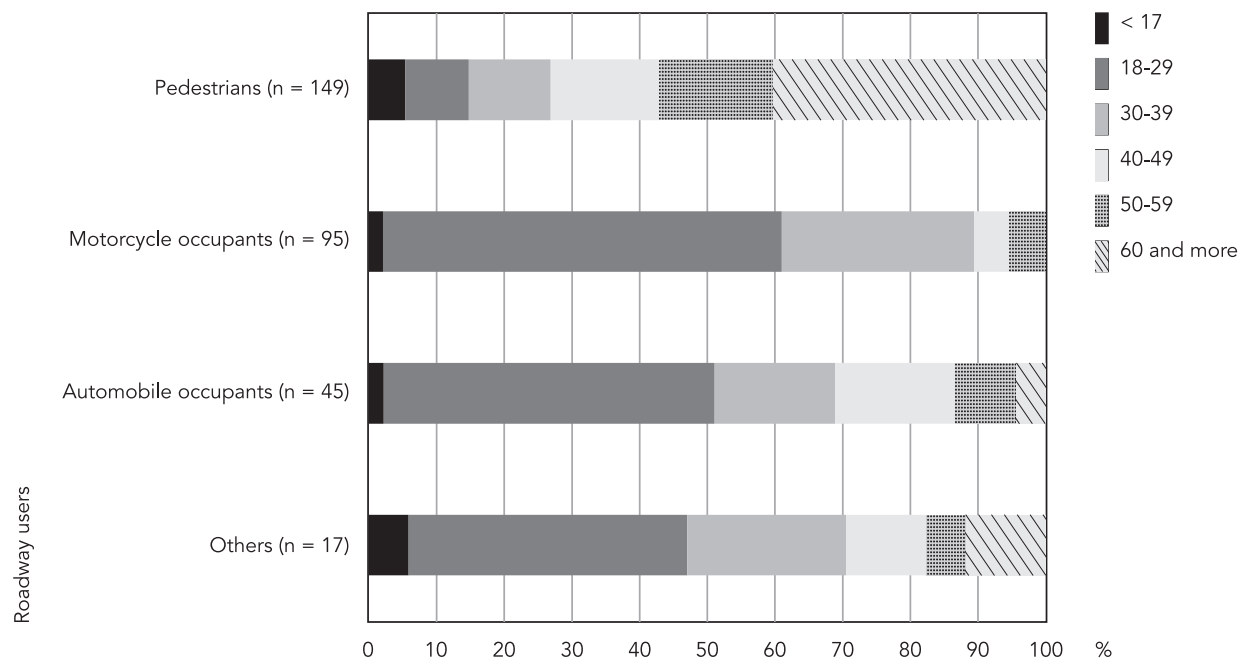

(continues)

$32 \%$ at the crash site. Of the men, $43 \%$ were pedestrians, $37 \%$ motorcycle occupants, and $41 \%$ died at the crash site (data not shown).

Univariate Poisson regression analysis (Table 2) indicates that the mean number of deaths was: (a) $68 \%$ greater in motorcycle occupants than in heavy vehicle occupants; (b) $29 \%$ greater in men than women; and (c) $83.3 \%$ and $30.6 \%$ higher, respectively, in the 18-29 and 60 and older age bracket when compared to individuals under 18 


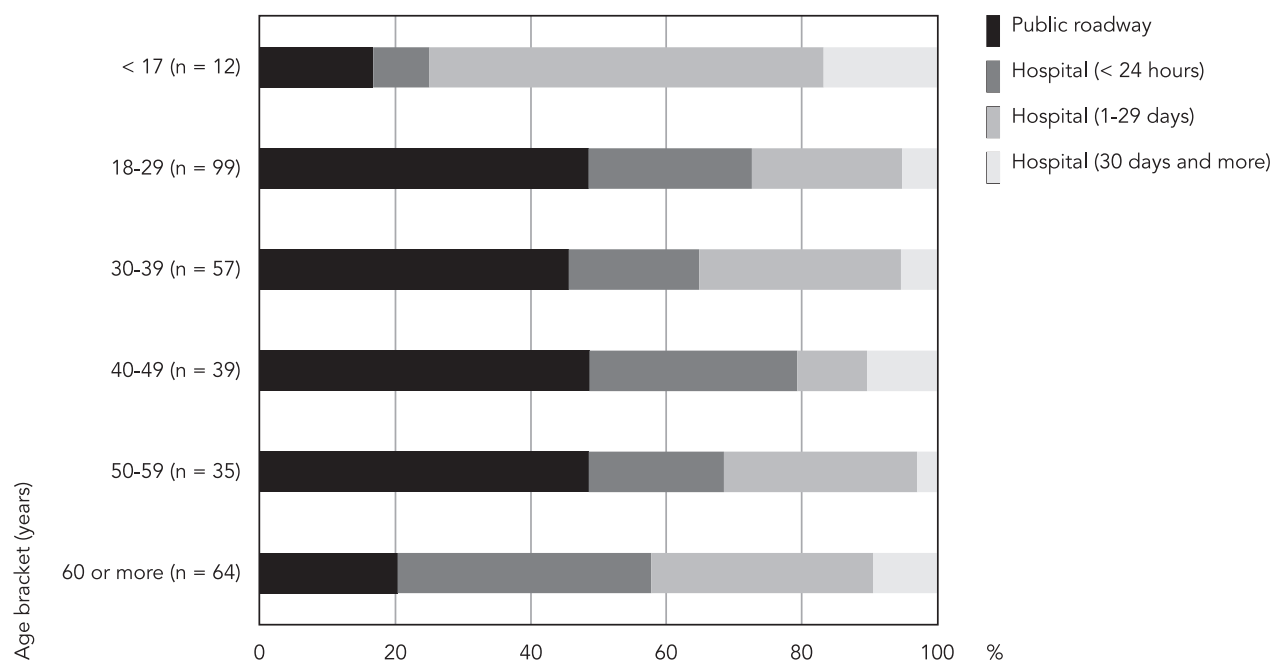

2d) Place and time and roadway user

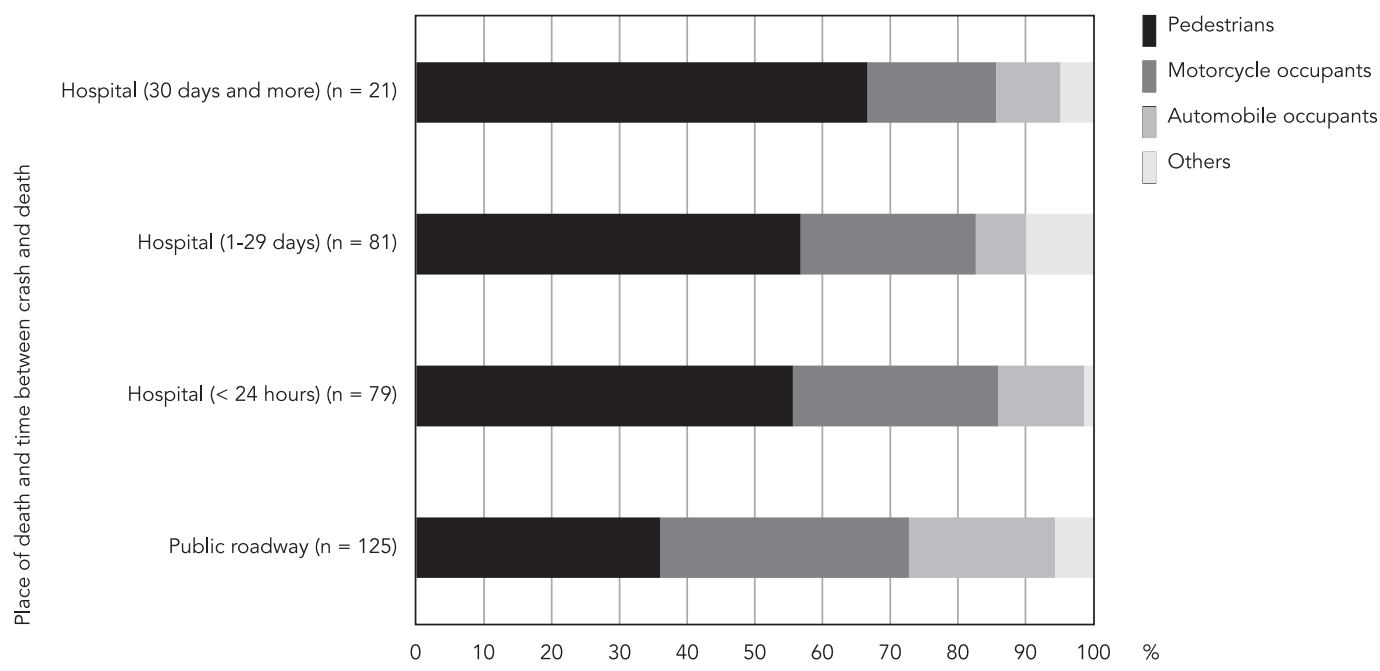

years of age. As for marital status, for single or divorced individuals the mean number of deaths was $23.8 \%$ greater than for married. Skin color and schooling did not differ significantly $(\mathrm{p}>$ 0.05 ) from the respective reference categories.

There was a $43 \%$ increase (RR: $1.43 ; 95 \% \mathrm{CI}$ : 1.12-1.83) in the mean number of deaths at the crash site compared to in-hospital and a $34 \%$ increase (RR: 1.34; 95\%CI: 1.11-1.62) within 24 hours when compared to $\geq 30$ days between the crash and death.

The final multivariate model (Table 3 ) showed a higher mean number of deaths among motorcycle occupants (RR: 1.81; 95\%CI: 1.29- 2.55) and pedestrians (RR: 1.32; 95\%CI: 1.02-1.71) compared to heavy vehicle occupants, after adjusting for gender, marital status, age bracket, and "place and time of death". Maintaining the other 
Final multivariate Poisson regression model.

\begin{tabular}{|c|c|c|c|c|}
\hline Variables & B & p-value * & RR & $95 \% \mathrm{Cl}$ \\
\hline Intercept & -0.909 & $<0.001$ & 0.403 & $0.248-0.654$ \\
\hline \multicolumn{5}{|l|}{ Roadway users } \\
\hline Pedestrians & 0.278 & 0.035 & 1.321 & $1.020-1.711$ \\
\hline Motorcycle occupants & 0.594 & 0.001 & 1.812 & $1.286-2.552$ \\
\hline Automobile occupants & 0.118 & 0.359 & 1.125 & $0.875-1.448$ \\
\hline Bicycle occupants & -0.113 & 0.396 & 0.893 & $0.687-1.160$ \\
\hline Heavy vehicles & - & & 1.000 & \\
\hline \multicolumn{5}{|l|}{ Gender } \\
\hline Male & 0.214 & 0.005 & 1.238 & $1.065-1.439$ \\
\hline Female & - & & 1.000 & \\
\hline \multicolumn{5}{|l|}{ Age bracket (years) } \\
\hline$\geq 60$ & 0.468 & 0.000 & 1.597 & $1.240-2.057$ \\
\hline $50-59$ & 0.326 & 0.016 & 1.385 & $1.062-1.805$ \\
\hline $40-49$ & 0.312 & 0.047 & 1.366 & $1.004-1.858$ \\
\hline $30-39$ & 0.218 & 0.060 & 1.243 & $0.991-1.560$ \\
\hline $18-29$ & 0.557 & 0.000 & 1.746 & $1.331-2.291$ \\
\hline$\leq 17$ & - & & 1.000 & \\
\hline \multicolumn{5}{|l|}{ Marital status } \\
\hline Widowed & 0.202 & 0.262 & 1.224 & $0.860-1.743$ \\
\hline Single/Divorced/Separated & 0.245 & 0.008 & 1.277 & $1.065-1.532$ \\
\hline Married & - & & 1.000 & \\
\hline \multicolumn{5}{|l|}{ 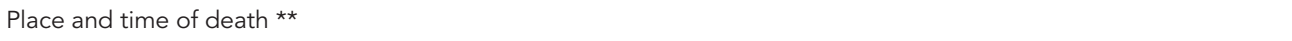 } \\
\hline Roadway & 0.331 & 0.003 & 1.392 & $1.115-1.737$ \\
\hline Hospital (<24 hours) & 0.093 & 0.348 & 1.097 & $0.904-1.331$ \\
\hline Hospital (1-29 days) & 0.178 & 0.510 & 1.195 & $0.999-1.430$ \\
\hline Hospital ( $\geq 30$ days) & - & & 1.000 & \\
\hline
\end{tabular}

95\% $\mathrm{Cl}$ : $95 \%$ confidence interval; RR: rate ratio.

* Wald test;

** Variable created from the variables place of death and time between crash and death.

variables constant, the mean number of deaths was $24 \%$ greater in men than in women (RR: 1.24 95\%CI: $1.079-1.44), 27 \%$ greater among single or divorced/separated individuals than married (RR: 1.27; 95\%CI: 1.07-1.53); and 75\% and 60\% higher among young individuals 18 to 29 years of age and elderly, respectively (RR: 1.75; 95\%CI: 1.33-2.29 and RR: 1.60; 95\%CI: 1.24-2.06) when compared to individuals under 18 years of age.

The mean number of deaths on the public roadway was $39 \%$ greater (RR: 1.39 ; $95 \% \mathrm{CI}$ : 1.12 1.74) when compared to in-hospital deaths at 30 days or more after the crash. The final model was statistically significant according to the Omnibus test $(\mathrm{p}=0.022)$.

Since a strong association was identified between age bracket and roadway user category $(p<0.01)$, we tested the inclusion of an interac- tion factor in the model, but the model with the interaction term was not statistically significant (Omnibus test, $\mathrm{p}=0.266$ ).

\section{Discussion}

The study showed the relevance of road traffic accidents as a public health problem, calling attention to the severity in young, single or divorced/separated males, motorcycle occupants, and the elderly (as pedestrians), characterizing these as highly vulnerable groups. The analysis unveils road traffic violence through the high proportion of deaths at the crash site and within the first 24 hours, suggesting that this type of violence poses a major threat to Brazilians' lives, along with homicides 6 . The findings on the pre- 
dominance of elderly (40\%) among pedestrians and of young people in the other roadway user categories corroborate previous studies 3,8 and reinforce the idea that the use of urban space in Brazilian cities, characterized by huge population clusters, has led to unjust inequalities in roadway use, prioritizing automobiles and individual transportation to the detriment of pedestrian mobility and users of public transportation (the latter consisting mainly of low-income individuals). All this calls for interventions to reduce social inequalities 20 .

The system's structural design prioritizes the demands for ease in commuting by automobile to the detriment of safety as a whole 21,22 , thereby generating inequalities, as demonstrated here by the increased vulnerability of two age groups: first, young males 18 to 29 years of age and their use of motorcycles as a means of transportation and/or work 3,15,23,24 and second, the elderly (generally run over in traffic), with $60 \%$ more deaths when compared to individuals under 18 years of age. The situation with the elderly reveals their precarious relationship with the urban space, which fails to allow for their limited functional capacity (especially problems with gait and eyesight). This difficult relationship is expressed in the stoplights, which involve excessive waiting times and are insufficient to guarantee safe crossing by pedestrians. It is also common for the elderly to experience difficulty in understanding the signage and logic of the traffic flow, especially at crosswalks and particularly due to low schooling among a large proportion of elderly Brazilians 3,8.

The lower number of deaths among bicycle occupants, whose vulnerability has been identified by descriptive studies 3,25 , may be explained by the fact that bicycles are still not a common means of local transportation, probably due to cultural issues and the city's hilly relief.

Among female victims of fatal accidents, the large shares of pedestrians (75\%) and automobile occupants (20\%) also confirm data from the literature 3 .

The severity of road traffic accidents within the city limits was shown by the high rates of deaths at the crash site (39\%) or in the first 24 hours (67\%), when compared to deaths 30 days after the crash or later, which is also consistent with other studies 1,15. In addition, the high percentage of deaths at the crash site among automobile occupants (who are not the most vulnerable of all roadway users) emphasizes the severity of urban road traffic accidents and the importance of imposing stricter speed limits inside the city limits.

These findings expand the discussion on the improvement of pre-hospital and hospital treat- ment, essential for the reduction of case-fatality from road traffic accidents. Emergency medicine has defined 60 minutes as an important prognostic factor for such injuries 21 .

The study did not find a statistically significant association between the number of deaths and skin color or schooling ( $\mathrm{p}>0.05)$. However the fact that $60 \%$ of victims were brown or black (a higher proportion than in the local population) and that $47 \%$ of the deaths occurred in individuals with low schooling suggests the involvement of social factors, possible markers of the victims' social and economic status, with roots in social determinants of health 26,27 . These results corroborate the findings from the VIVA survey, showing a similar percentage for Brazil's state capitals as a whole 28 .

The urban environment in countries with social inequalities, resulting from disorderly growth and lack of control over economic activity (the management of which has been delayed by pressures from globalization) 26,29 , conditions and stimulates the use of motorcycles as a means of transportation and work. This trend has been observed in various countries 1,30 , including Brazil 27,28,31, where motorcycle sales increased twelve-fold while automobile sales increased four-fold from 1992 to 2007 . Motorcycles have been purchased more by lowerincome groups, influenced by easy credit and stimulated by the Federal government 22 and the creation of new outsourced jobs as motorcycle delivery boys and motorcycle taxi drivers 32. Motorcycles facilitate speed as an ideal in social and economic practices, but increases the occupants' exposure and vulnerability, while the resulting risk is taken for granted by the young males comprising this group 23,24. Contextual factors permeating inefficient traffic laws, which fail to prohibit motorcyclists from passing between lines of automobiles in adjacent traffic lanes 33 , and insufficient intervention by government authorities, represented by the exponential increase in motorcycles on public roadways, further aggravate the problem 34 .

From the methodological point of view, database linkage of road traffic accidents was based on the experience of other authors in studies on mortality 15 and morbidity 14 . The strategy confirmed that the two data sources were complementary, by comparing them to the final linked database (BH10-SIM). The strategy demonstrated that the exclusive use of information from the mortality database (SIM) fails to adequately identify roadway users involved in accidents or the time interval between the crash and death, which are essential for determining the profile of these deaths. Neither does it allow discriminating 
between road traffic accidents that occur inside the city limits or on highways, or even in other municipalities (counties), since the SIM nearly always records the place of death rather than the crash site.

Meanwhile, the victim's personal data on the police crash reports are limited to name, age, and gender, thus hampering or even impeding an adequate description. The information on police records tends to underestimate deaths ${ }^{3}$, since it almost exclusively covers the occurrence on the roadway and thus generates a different profile from that in the database linked with the SIM.

The 24\% under-recording rate was higher than that reported in a study from Spain $(6.6 \%)$ and highlighted the importance of using patient medical records for deaths that occurred more than 24 hours after the crash 15 . The current study showed $7 \%$ of deaths from road traffic accidents at 30 days or more after the crash, suggesting the limit proposed by the World Health Organization (WHO) 2, which may be underestimating these indicators.

Mortality rates from road traffic accidents with Belo Horizonte residents within the city limits may also lead to underestimation of this indicator, hindering or even impeding comparison with data from the literature, since most studies do not analyze only deaths from accidents the occur in the city, rather examining deaths of the city's residents, regardless of where the crash occurs. The risk of dying in the city from road traffic accidents showed differences by gender and age bracket, much higher in men and in two age extremes (young people and elderly), findings that are consistent with the analyses of total deaths.

The study's strengths included the integration of different data sources to upgrade the information in identifying the profiles of vulnerable roadway users. However, it also presents some weaknesses.

Information bias is a common limitation when using secondary records, not originally collected according to the current study's objectives. The SIM does not always provide relevant data on the circumstances of the deaths, while data from police reports, filled out by police officers at the crash site, may omit crucial information for understanding the occurrence.

Record linkage certainly upgrades the information, but it may predispose to errors in the various stages of the process, ranging from data entry in the identification to the comparison of data from the different systems (a painstaking, monotonous, and time-consuming activity). However, careful manual revision of the true pairs and detailed searches for inconsistencies certainly minimized the occurrence of potential errors.

The data improvement allowed more realistic estimation of fatal road traffic accidents, adding $24 \%$ more deaths to the database and providing a more precise profile of the victims. Another limitation was the impossibility of calculating mortality rates from accidents that occurred in Belo Horizonte, due to the difficulty in estimating the population exposed to risk. However, Poisson regression allowed estimating the number of deaths from road traffic accidents as a function of the available explanatory variables.

The study emphasizes the relevance of premature death in an economically active population, an important workforce with numerous family providers, entailing irreparable loss to society and the country. The study further signals that the solution to road traffic violence requires integrated, sustained inter-sector measures, where the identification of environmental factors that influence injuries from road traffic accidents should be used in urban planning through the interface between public health and other fields, promoting preventive and protective interventions.

The results also emphasize the need for studies that monitor educational measures, including traffic behavior and alcohol and other drug use by motorists and victims (including pedestrians), in addition to detailed analyses of roadways with the most pedestrian victims and fatal accidents. They also contribute to discussion of more specific interventions, as well as mobility policies with improvements in the urban space, prioritizing the vulnerable groups, better public transportation, speed control with rigorous and permanent surveillance, in addition to strategies to guarantee timely and qualified pre-hospital and hospital care.

Considering that injuries from road traffic accidents result from the interaction between persons, vehicles, and the environment, health and urban planning should be organized to respond to the population's current needs in mobility and transportation, ensuring quality of life and protection, especially for vulnerable groups - pedestrians, users of non-motorized transportation, and motorcyclists.

Road traffic without violence is an expression of citizenship, translated as the social responsibility of all stakeholders - roadway users, the automobile industry, transportation companies, especially urban transportation, and government - to build safe environments.

The multidisciplinary identification of factors that influence injuries from road traffic accidents, conducted by specialists in urban planning, 
traffic control, and public health, should contribute to the definition of protective interventions aimed at avoiding injuries, disabilities, and deaths and to the creation of a safer environment.

Changes in vehicles and roadways are among the most successful strategies to reduce traffic injuries and accounted for the improvement in mortality rates in the $20^{\text {th }}$ century. Simultaneous strategies to build a protective environment against road traffic injuries, modifications in vehicle safety, inspection, and educational interventions for behavior changes emphasize the collective and individual responsibilities that are indispensable to reduce injuries from traffic accidents.
Symbolic representations of motor vehicles in contemporary society are associated with social status and power, including perceived prestige, freedom, and pleasure. An important challenge is to mobilize the population for safe attitudes and solidarity in compliance with the law and responsibility in traffic, reinforcing the idea that road traffic accidents should not be taken for granted or considered inevitable, but amenable to prevention and control through effective measures to keep citizens from becoming victims when exercising their fundamental right to come and go.

\section{Resumen}

El estudio compara el perfil de óbitos por accidentes de tráfico en Belo Horizonte, Minas Gerais, Brasil, entre dos sistemas de información pública y los caracteriza a partir del cruce de las bases de datos de tráfico (BH10) y de mortalidad (SIM). El banco relacionado $(n=306)$ ha apuntado un subregistro del $24 \%$ de óbitos y ha diferido en cuanto a la distribución etaria con el BH1O y usuarios de vías respecto al SIM. La tasa de mortalidad en el perímetro urbano ha sido de 10,02/100 mil residentes, mayor entre hombres, jóvenes y ancianos. La regresión multivariante de Poisson mostró un mayor número promedio esperado de óbitos entre ocupantes de motocicletas (razón de momioRM: 1,81); peatones (RM: 1,32); hombres (RM: 1,24); solteros/separados (RM: 1,27); jóvenes de 18-29 años (RM: 1,75) y ancianos (RM: 1,59) y en el sitio del accidente (RM: 1,39), cuando eran comparadas con las categorías de referencia. El estudio señala la importancia de la interrelación entre sistemas de información para caracterizar los óbitos por accidentes de tráfico en el área urbana, revelando así su magnitud y el escenario de violencia en el tráfico.

Acidentes de Tránsito; Mortalidad; Sistemas de Información; Salud Urbana

\section{Contributors}

L. M. M. M. Paixão participated in the study conceptualization, data search, analysis, and interpretation, and writing and final revision of the article. E. D. Gontijo and W. T. Caiaffa participated in the study conceptualization and design, data interpretation, and writing and final revision of the article. S. A. Mingoti and D. A. S. Costa participated in the data analysis and interpretation and revision of the article. A. A. L. Friche participated in the data interpretation and revision of the article.

\section{Acknowledgments}

The authors wish to thank the Belo Horizonte Urban Transportation and Transit Company (BHTRANS) and the Belo Horizonte Municipal Health Secretariat for kindly providing access to the data. To CNPq for the productivity scholarship granted to $\mathrm{W}$. T. Caiaffa. 
1. Kanchan T, Kulkarni V, Bakkannavar SM, Kumar N Unnikrishnan B. Analysis of fatal road traffic accidents in a coastal township of South India. J Forensic Leg Med 2012; 19:448-51.

2. World Health Organization. Global status report on road safety: time for action. http://who.int/vio lence_injury_prevention/road_safety_status/2009 (accessed on 24/Jul/2012).

3. Spoerri A, Egger M, von Elm E. Mortality from road traffic accidents in Switzerland: longitudinal and spatial analyses. Accid Anal Prev 2011; 43:40-8.

4. Mello Jorge MHP, Koizumi MS. Acidentes de trânsito no Brasil: um atlas de sua distribuição. São Paulo: Associação Brasileira de Medicina de Tráfego; 2007.

5. Sleet DA, Naumann RB, Rudd RA. Injuries and the built environment. In: Dannemberg AL, Frunkin H, Jackson RJ, editors. Making health places: designing and building for health, well-being and sustainability. Washington DC: Island Press; 2011. p. 77-89.

6. Souza ER, Minayo MCS, Malaquias JV. Violência no trânsito: expressão da violência social. In: Ministério da Saúde, editor. Impacto da violência na saúde dos brasileiros. Brasília: Ministério da Saúde; 2005. p. 279-312.

7. Nunes MN, Nascimento LFC. Internações hospitalares por acidentes de moto no Vale do Paraíba. Rev Assoc Med Bras 2010; 56:684-7.

8. Bacchieri G, Barros AJD. Acidentes de trânsito no Brasil de 1998 a 2010: muitas mudanças e poucos resultados. Rev Saúde Pública 2011; 45:949-63.

9. Haddon Jr. W. The changing approach to the epidemiology, prevention, and amelioration of trauma: the transition to approaches etiologically rather than descriptively based. Am J Public Health Nations Health 1968; 58:1431-8.

10. Ministério da Saúde. Portaria GM/MS no 737, de 16 de maio de 2001. Diário Oficial da União 2001; 18 mai.

11. Mascarenhas MDM, Silva MMA, Malta DC, Moura L, Macário EM, Gawryszewski VP, et al. Perfil epidemiológico dos atendimentos de emergência por violências no sistema de serviços sentinela de vigilância de violências e acidentes (VIVA). Epidemiol Serv Saúde 2009; 18:17-28.

12. Morais Neto OL, Silva MMA, Lima CM, Malta DC, Silva Jr. JB. Projeto Vida no Trânsito: avaliação das ações em cinco capitais brasileiras, 2011-2012. Epidemiol Serv Saúde 2013; 22:373-82.

13. Cabral APS, Souza WV, Lima MLC. Serviço de Atendimento Móvel de Urgência: um observatório dos acidentes de transportes terrestre em nível local. Rev Bras Epidemiol 2011; 14:3-14.

14. Cryer PC, Westrup S, Ashwell V, Bridger P, Clarke C. Investigation of bias after data linkage of hospital admissions data to police road traffic crash reports. Inj Prev 2001; 7:234-41.

15. Pérez C, Cirera E, Borrell C, Plasència A. Motor vehicle crash fatalities at 30 days in Spain. Gac Sanit 2006; 20:108-15.
16. Ministério da Saúde; Conselho Federal de Medicina. A Declaração de Óbito: documento necessário e importante. 2a Ed. Brasília: Ministério da Saúde; 2007.

17. Szklo M, Nieto FJ. Epidemiology: beyond the basics. 3rd Ed. Burlington: Jones and Bartlett Learning; 2012.

18. Dobson A, Barnett A. An introduction to generalized linear models. $3^{\text {rd }}$ Ed. New York: Chapman \& Hall; 2008.

19. Paula GA. Modelos de regressão com apoio computacional. São Paulo: Instituto de Matemática e Estatística, Universidade de São Paulo; 2010.

20. Hyder A, Peden M. Inequality and road-traffic injuries: call for action. Lancet 2003; 362:2034-5.

21. Marini RL. Acidentes de trânsito em Belo Horizonte: fatores associados ao atendimento pré-hospitalar, internações e óbitos em 1994 e 2003 [PhD Dissertation]. Belo Horizonte: Faculdade de Medicina, Universidade Federal de Minas Gerais; 2007.

22. Vasconcelos EA. O custo social da motocicleta no Brasil. Revista dos Transportes Públicos 2008; 30/31:127-42.

23. Silva PHNV. Epidemiologia dos acidentes de trânsito com foco na mortalidade de motociclistas no estado de Pernambuco: uma exacerbação da violência social [PhD Dissertation]. Recife: Centro de Pesquisas Ageu Magalhães, Fundação Oswaldo Cruz; 2012.

24. Legay LF, Santos SA, Lovisi GM, Aguiar JS, Borges JC, Mesquita RM, et al. Acidentes de transporte envolvendo motocicletas: perfil epidemiológico das vítimas de três capitais de estados brasileiros, 2007. Epidemiol Serv Saúde 2012; 21:283-92.

25. Freitas JPP, Ribeiro LA, Jorge MT. Vítimas de acidentes de trânsito na faixa etária pediátrica atendidas em um hospital universitário: aspectos epidemiológicos e clínicos. Cad Saúde Pública 2007; 23:3055-60.

26. Caiaffa WT, Friche AAL. Urbanization, globalization and road safety: a potential dialogue in search of equity? Ciênc Saúde Coletiva 2012; 17:2238-41.

27. Montenegro MMS, Duarte EC, Prado RR, Nascimento AF. Mortalidade de motociclistas em acidentes de transporte no Distrito Federal, 19962007. Rev Saúde Pública 2011; 45:529-38.

28. Malta DC, Bernal RT, Mascarenhas MDM, Monteiro RA, Sá NNB, Andrade SSCA, et al. Atendimentos por acidentes de transporte em serviços públicos de emergência em 23 capitais e no Distrito FederalBrasil, 2009. Epidemiol Serv Saúde 2012; 21:31-42.

29. Golias ARC, Caetano R. Acidentes entre motocicletas: análise dos casos ocorridos no estado do Paraná entre julho de 2010 e junho de 2011. Ciênc Saúde Coletiva 2013; 18:1235-46.

30. Guoqing H. Comparing road traffic mortality rates from police-reported data and death registration data in China. Bull World Health Organ 2011; 89:41. 
31. Morais Neto OL, Montenegro MMS, Monteiro RA, Siqueira Junior JB, Silva MMA, Lima CM, et al. Mortalidade por acidentes de transporte terrestre no Brasil na última década: tendência e aglomerados de risco. Ciênc Saúde Coletiva 2012; 17:2223-36.

32. Silva PHNV, Lima MLC, Moreira RS, Souza WV, Cabral APS. Estudo espacial da mortalidade por acidentes de motocicleta em Pernambuco. Rev Saúde Pública 2011; 45:409-15.
33. Brasil. Lei no 9.503, de 23 de setembro de 1997. Institui o Código de Trânsito Brasileiro. Diário Oficial da União 1997; 24 set.

34. Minayo MCS. Morre menos quem morre no trânsito? Ciênc Saúde Coletiva 2012; 17:2237-8.

Submitted on 26/May/2014

Final version resubmitted on 11/Sep/2014

Approved on 16/Sep/2014 